\begin{tabular}{|c|c|c|}
\hline$\underset{\text { Homepage: http://jusami.batan.go.id }}{\|}$ & Jurnal Sains Materi Indonesia & $\begin{array}{l}\text { Akreditasi LIPI } \\
\text { No.: 602/AU3/P2MI-LIPI/03/2015 } \\
\text { Tanggal 15 April } 2015 \\
\text { ISSN : 1411-1098 }\end{array}$ \\
\hline
\end{tabular}

\title{
MAGNETIC REDUCED GRAPHENE OXIDE AS ADVANCED MATERIALS FOR ADSORPTION OF METAL IONS
}

\author{
Andri Hardiansyah', Elsy Rahimi Chaldun² and Amelia Fadyah Idzni ${ }^{1}$ \\ ${ }^{1}$ Fakultas Teknik dan Desain - Institut Teknologi dan Sains Bandung \\ Jl. Ganesha Boulevard, Cikarang Pusat, Pasirranji, Bekasi 17530 \\ ${ }^{2}$ Research Unit for Clean Technology - Indonesian Institute of Sciences \\ Jl. Cisitu 154D, Bandung 40135 \\ E-mail: andri.hardiansyah1988@gmail.com
}

Received: 15 May 2017 Revised: 6 July $2017 \quad$ Accepted: 14 July 2017

\begin{abstract}
MAGNETIC REDUCED GRAPHENE OXIDE AS ADVANCED MATERIALS FORADSORPTION OF METAL IONS. Magnetic Reduced Graphene Oxide (MRGO) is graphene-based material that modified by introducing iron oxide nanoparticles onto the surface of graphene oxide (GO). MRGO exhibit some unique and advanced properties and characteristic including high surface area, superparamagnetic characteristics and adsorption ability against ions and molecules. In this research, MRGO was prepared by the Hummers method, followed by reacting ferrochloride tetrahydrate and ferrichloride hexahydrate through co-precipitation method for the formation of iron oxide nanoparticles on the GO surface. MRGO was prepared with various composition of ferrochloride tetrahydrate. Furthermore, the resultant of MRGO was characterized by Scanning Electron Microscope (SEM), Fourier-transform Infrared (FT-IR) Spectroscopy, and Atomic Adsorption Spectroscopy (AAS). Adsorption characteristics test was conducted against electroplating waste-based metal ion. The SEM results showed that GO exhibited the layered structure meanwhile MRGO exhibit as Fef $\mathrm{O}_{4}$-modified GO layered surfaces. MRGO made by different ferrochloride tetrahydrate differed in the iron oxide nanoparticles formation on the surface of GO. Increasing the composition of ferrochloride tetrahydrate increased the formation of iron oxide nanoparticles. Moreover, MRGO $(\mathrm{FeCl}, .4 \mathrm{H}, \mathrm{O} 0.0064 \mathrm{M})$ is successfully applied as nickel metal ion adsorbents with the adsorption ability of $78,24 \%$. This result showed that MRGO have a potential prospect as an effective and efficient advanced adsorbent material candidate.
\end{abstract}

Keywords: Graphene oxide (GO), Magnetic nanoparticles, Adsorption

\begin{abstract}
ABSTRAK
MAGNETIC REDUCED GRAPHENE OXIDE SEBAGAI MATERIAL MUTAKHIR UNTUK PENYERAPAN ION LOGAM. Magnetic Reduced Graphene Oxide (MRGO) merupakan material berbasis graphene yang dimodifikasi dengan adanya nanopartikel besi oksida pada permukaan Graphene Oxide (GO). $M R G O$ menampilkan sifat dan karakter yang unik dan mutakhir seperti luas permukaan yang tinggi, karakter superparamagnetik serta kemampuan penyerapan terhadap ion dan molekul. Pada penelitian ini, MRGO dipreparasi dengan menggunakan metode Hummer yang diikuti dengan mereaksikan ferrochloride tetrahydrate dan ferrichloride hexahydrate melalui metode kopresipitasi untuk membentuk nanopartikel besi oksida pada permukaan GO. MRGO dipreparasi dengan memvariasikan konsentrasi prekursor ferrochloride tetrahydrate. Selanjutnya, MRGO yang dihasilkan dikarakterisasi dengan menggunakan Scanning Electron Microscope (SEM), Fourier-Transform Infrared (FT-IR) Spectroscopy, dan Atomic Adsorption Spectroscopy (AAS). Karakter adsorpsi diuji dengan menggunakan ion logam nikel. Hasil observasi $S E M$ menunjukkan bahwa $G O$ menampilkan struktur lapisan sedangkan pada $M R G O$ menampilkan adanya nanopartikel besi oksida pada lapisan permukaan $G O$. $M R G O$ menampilkan sebaran nanopartikel besi oksida yang berbeda pada konsentrasi yang berbeda. Peningkatan konsentrasi awal prekursor ferrochloride tetrahydrate akan meningkatkan pembentukan nanopartikel besi oksida pada $G O . M R G O\left(\mathrm{FeCl}_{2} \cdot 4 \mathrm{H}_{2} \mathrm{O} 0,0064 \mathrm{M}\right)$ dapat diaplikasikan pada ion nikel sebagai adsorben dengan kemampuan absorspi sebesar 78,24\%. Hasil ini menunjukan bahwa $M R G O$ memiliki prospek yang potensial sebagai kandidat material untuk adsorben ion logam yang efektif dan efisien.
\end{abstract}

Kata kunci: Graphene oxide (GO), Nanopartikel magnetik, Adsorpsi 


\section{INTRODUCTION}

Treatment of waste is in needed in order to develop a green environment. Metallic ions that discharge into the environment as a waste from the factory could become a serious problem for the human and its environment. The system that could adsorb metallic ions become an emerging issue to overcome these problems.

Recently, nanotechnology plays an important role as a prospect technology that could be developed to overcome the human problems. Various advanced materials have been developed as adsorbent materials including nanoparticles, polymeric-based material, ceramic-based materials, and nanocomposites materials.

Nowadays, graphene oxide $(\mathrm{GO})$ materials have obtained a great of interest both scientist and technician [1]. GO could be synthesized through well-developed process and method namely chemical exfoliation [2]. GO possesses several unique and powerful properties including high surface area and accessible for chemical or physical functionalization. Moreover, GO possesses a good characteristics as a potential adsorbent materials [3]. Various applications have been developed by using GO such as for biodetection [2], SERS detection [4], supercapacitors [5], nano-filler [6], drug carrier [7] and absorbent for dye molecules [8].

Magnetic nanoparticles exhibit unique and powerful properties that could be elaborated in term of their size and their ability to interact with external magnetic field exposure [9]. Magnetic nanoparticles could be prepared through co-precipitation method [10].

Furthermore, external magnetic field have been developed as a promising stimuli system to triggered some functions and characteristics. External magnetic field could be used directly to the magnetic materials system without contact forces.

For instance, magnetic force has been developed as absorption assisted process for magnetic-based separation or filtration [8]. GO could be combine with magnetic nanoparticles in order to developed magnetic reduced graphene oxide (MRGO). Furthermore, MRGO could be developed as a template for detection of molecules and metal ions through magnetic separation techniques $[1,3,8,11]$.

In this study, MRGO was developed through the preparation of GO materials followed by the in situ self-assembly formation of iron oxide nanoparticles on the surface of GO. The structures and morphology of MRGO were evaluated systematically by using SEM and FT-IR spectroscopy. Absorption and separation processes were evaluated through atomic absorption spectroscopy (AAS) data.

\section{EXPERIMENTAL METHOD}

\section{Materials}

Graphite powder $(<20 \mu \mathrm{m}$ synthetic), ferro chloride tetrahydrate, ferrichloride hexahydrate and fuming nitric acid $\left(\mathrm{HNO}_{3}\right)$ were purchased from SigmaAldrich. Potassium permanganate $\left(\mathrm{KMnO}_{4}\right)$ and sulfuric acid $\left(\mathrm{H}_{2} \mathrm{SO}_{4}\right)$ were purchased from Baker. Hydrogen peroxide $\left(\mathrm{H}_{2} \mathrm{O}_{2}\right)$ was purchased from Acros. Hydrochloric acid $(\mathrm{HCl})$ was purchased from Scharlau. All the chemicals were used without further purification.

Scanning Electron Microscope (SEM), Fouriertransform Infrared (FTIR) Spectroscopy, and Atomic Adsorption Spectroscopy (AAS) were used for identifying the structure, functional groups characteristics and metal ion absorption capability, respectively.

\section{Methods}

MRGO material was prepared via modified Hummer's method using flake expandable graphite as the original material followed by the in situ self-assembly of iron oxide nanoparticles on the surface of GO (Figure 1). Briefly, graphite flakes powder was mixed with concentrated sulfuric acid under homogeneous stirring for $1 \mathrm{~h}$. Subsequently, the suspension was put into water/ ice bath in order to keep the temperature below $5^{\circ} \mathrm{C}$. Afterwards, concentrated of nitric acid and potassium permanganate were added into the mixture and followed by stirring for 5 days. In the next step, deionized water was added slowly and stirred continuously for 2 hours. An aliquot of hydrogen peroxide was slowly added and continue stirring for 2 hours and left for 24 hours to precipitate the GO. Further, the supernatant was removed followed by adding distilled-water, $\mathrm{H}_{2} \mathrm{O}_{2}$ and $\mathrm{HCl}$ and continue with stirring for $2 \mathrm{~h}$ to stop the reaction. The resulting suspension of GO was then centrifuged at 4500 $\mathrm{rpm}$. Centrifugation process was conducted three times. The final suspension was washed by using deionized water until $\mathrm{pH}$ neutral was achieved. The product was dried at $40^{\circ} \mathrm{C}$ in vacuo which resulted in $\mathrm{GO}$ powder.

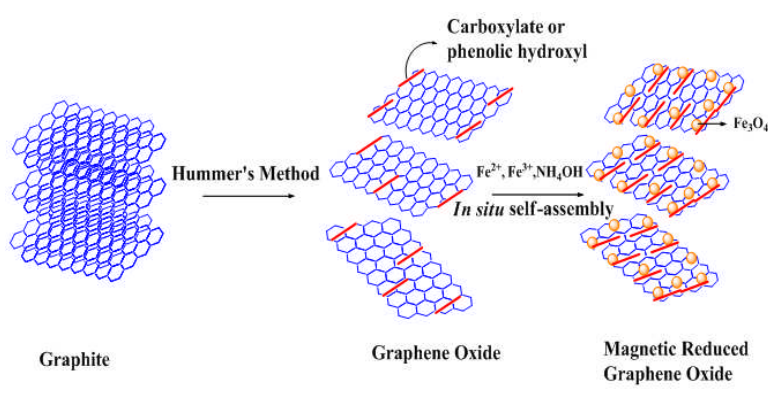

Figure 1. Preparation of magnetic reduced graphene oxide

In order to prepared the MRGO, an amount of ferrochloride tetrahydrate and ferrichloride hexahydrate 
were added into the GO suspension under the homogeneous mixing in the basic condition. Various initial concentration of $\mathrm{FeCl}, 4 \mathrm{H}, \mathrm{O}(0.0016,0.0032,0.0064$, and $0.0129 \mathrm{M}$ ), in which the ratio of $\mathrm{FeCl}_{2} \cdot 4 \mathrm{H}_{2} \mathrm{O}$ / $\mathrm{FeCl}_{3} \cdot 6 \mathrm{H}_{2} \mathrm{O}$ of $1: 2$, was used to observe the effect of initial precursor concentration on the surface and morphology of MRGO. Eventually, the MRGO was collected magnetically and washed several times by using deionized water.

The resultant materials were characterized in terms of its structure and morphology by using SEM and FT-IR spectroscopy. Nickel ion generated from electroplating-based waste was used to investigate the metal ion absorption process and mechanism triggered by external magnetic field (Figure 2). Briefly, MRGO was mixed with nickel ion solution then mixed through stirring for 6 hours. Afterwards, external magnetic field was applied to the suspension for 30 minutes. Atomic absorption spectroscopy (AAS) was used to analyze the metal ion concentration.

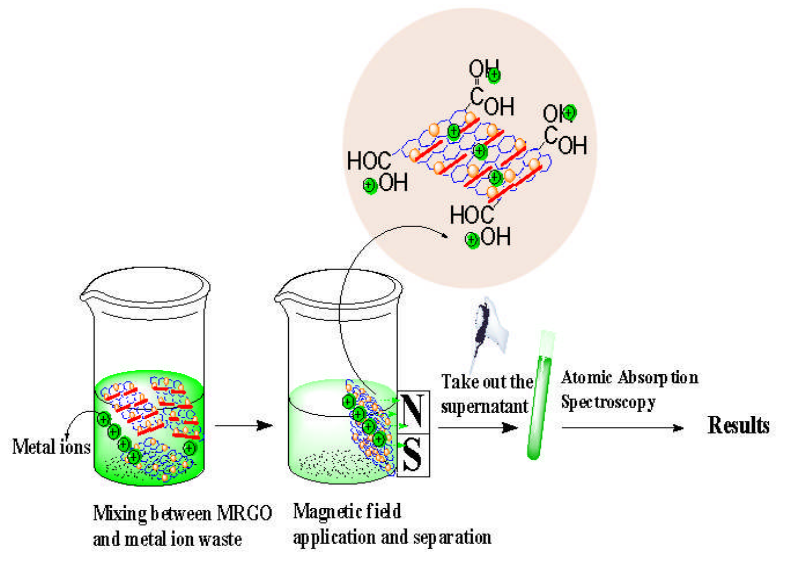

Figure 2. Schematic of magnetic-triggered absorption process

\section{RESULTS AND DISCUSSION}

Figure 3 shows the images of GO and MRGO in solution. GO material exhibited the dispersion on the aqueous solution. GO have no attraction under the application of external magnetic field. Interestingly, MRGO could easily interact with external magnetic field exposure. This phenomenon confirmed the

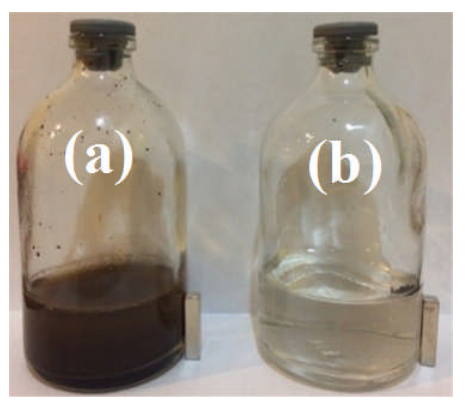

Figure 3. Images of GO (a) and MRGO (b) suspension under external magnetic field exposure superparamagnetic behaviors of MRGO in which the MRGO could attract easily during the external magnetic field applications, meanwhile without external magnetic field applications, the MRGO would dispersed again in the system without magnetic characteristics.

Figure 4 shows the SEM images of GO. GO exhibited sheets wrinkle structures. Chemical exfoliation based on Hummers's method could disintegrated the graphite layer through the reaction with strong acid followed by oxidation mechanism. Through this process, a few layers of GO could be developed simultaneously with the development of various chemical groups on the surface of GO. This result is in accordance with the previous investigation [8].

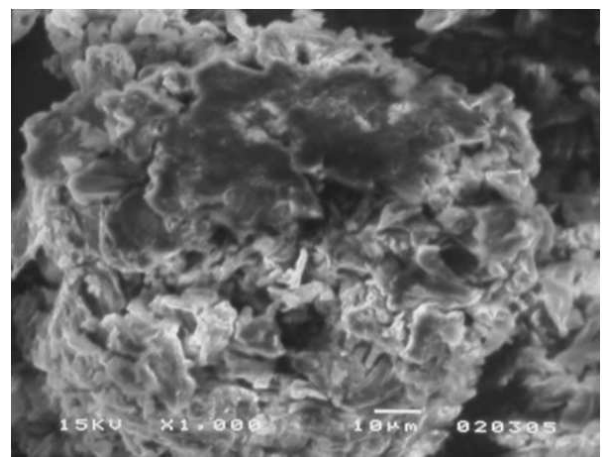

Figure 4. SEM images of GO

Figure 5 shows the FT-IR spectrum of graphite, GO, and MRGO. FT-IR spectrum of graphite exhibited no significant peaks that could be observed. Meanwhile, FTIR spectrum of GO and MRGO are intense with various functional groups due to the transformation process from graphite to GO and MRGO. FT-IR spectrum of GO at $3607 \mathrm{~cm}^{-1}$ due to hydroxyl $(\mathrm{O}-\mathrm{H})$ stretching, $1732 \mathrm{~cm}^{-1}$ for carbonyl $(\mathrm{C}=\mathrm{O})$ stretching, and $1222 \mathrm{~cm}^{-1}$ for $\mathrm{C}-\mathrm{OH}$ stretching. The stretching of $\mathrm{C}-\mathrm{O}$ could be observed at the wavenumber of $1076 \mathrm{~cm}^{-1}$. The peaks around $1106 \mathrm{~cm}^{-1}$ indicated the $\mathrm{C}-\mathrm{O}-\mathrm{C}$ epoxide stretching. The

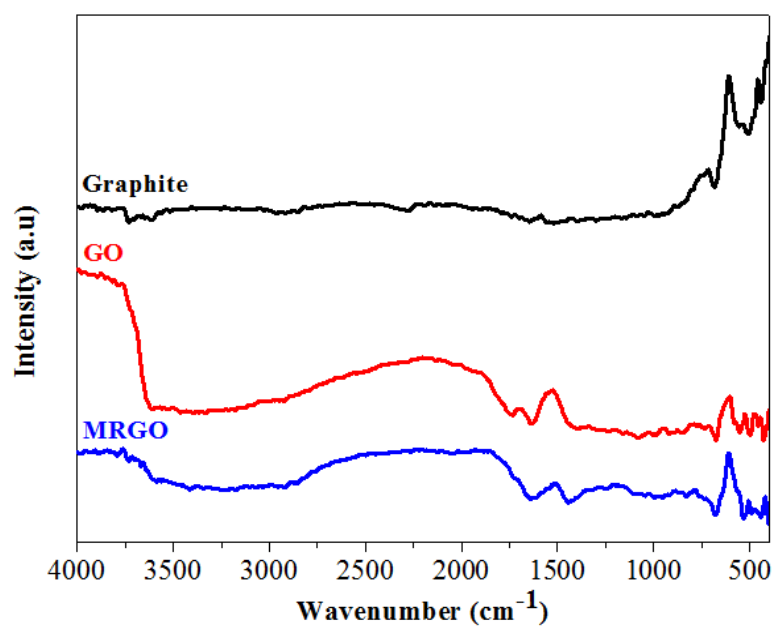

Figure 5. FT-IR spectrum of graphite, GO and MRGO. 
peak at around $1643 \mathrm{~cm}^{-1}$ indicated the $\mathrm{C}=\mathrm{C}$ aromatic stretching which confirmed the presence of $\mathrm{sp}^{2}$ hybridized honeycomb lattice. Meanwhile the $\mathrm{C}-\mathrm{H}$ aliphatic could be observe at wavenumber of $1390 \mathrm{~cm}^{-1}$, $874 \mathrm{~cm}^{-1}$ and $675 \mathrm{~cm}^{-1}$. The presence of these functional groups confirmed the presence of oxygen thus indicated the successful formation of graphene oxide through chemical exfoliation of graphite by hummer's method. Furthermore, the peaks at around $1732 \mathrm{~cm}^{-1}$ and $1390 \mathrm{~cm}$ ${ }^{1}$ for $\mathrm{C}=\mathrm{O}$ and $\mathrm{C}-\mathrm{H}$, respectively were slightly disappeared indicated the formation of MRGO. The peak of $\mathrm{C}=\mathrm{C}$ was also shifted which might be due to the modification of GO surface through iron oxide nanoparticles $\left(\mathrm{Fe}_{3} \mathrm{O}_{4}\right)$ immobilization. The peak at around 400-700 $\mathrm{cm}^{-1}$ confirmed the signature of $\mathrm{Fe}-\mathrm{O}$ in $\mathrm{Fe}_{3} \mathrm{O}_{4}$. Moreover, the peak at $1440 \mathrm{~cm}^{-1}$ confirmed the interaction between carboxylic groups with Fe which further confirmed the formation of MRGO, based on the interaction between $\mathrm{Fe}_{3} \mathrm{O}_{4}$ with GO.

Figure 6 shows the SEM images of MRGO with various concentration of $\mathrm{FeCl}_{2} \cdot 4 \mathrm{H}_{2} \mathrm{O}$. The iron oxide particles were developed in nearly spherical structures and attached homogeneously on the surface of graphene layer. SEM observation also revealed that increasing concentration of iron oxide precursor will increase the immobilization of iron oxide. This result is in accordance with the previous investigation $[3,11,12]$.
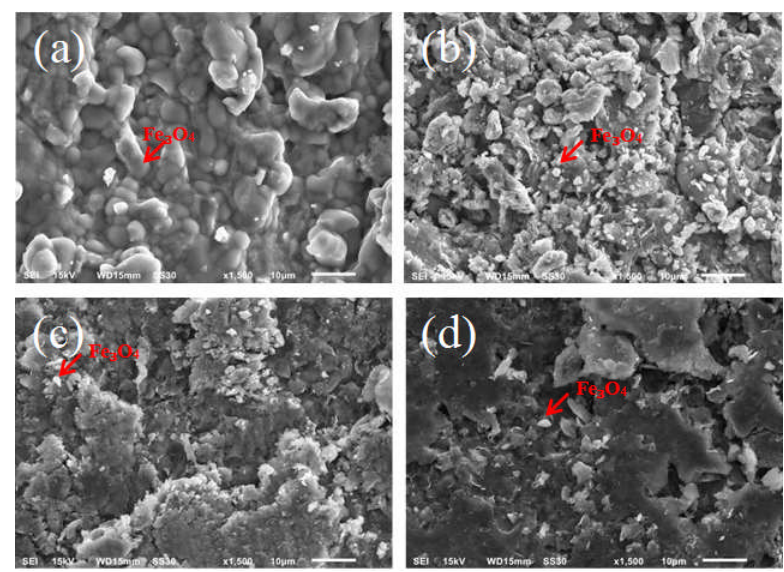

Figure 6. SEM images of MRGO with variation of $\mathrm{FeC}_{12} \cdot 4 \mathrm{H}_{2} \mathrm{O}$ concentration: (a). $0.0129 \mathrm{M}$, (b). $0.0064 \mathrm{M}$ (c). $0.0032 \mathrm{M}$ and (d). $0.0016 \mathrm{M}$.

Based on the measurement of magnetic separation experiment by using AAS, after 30 minutes of application of external magnetic field, the MRGO could absorb about $78,24 \%$ of nickel ion. These phenomena might be due to the development of sufficient electrostatic interaction among the negatively charge of functional groups containing residual oxygen with positively charge of adsorbates of nickel ion. Further, these results proved that MRGO could effectively absorb the metal ion and potentially applied for the metal ion-waste treatment and purification.

\section{CONCLUSION}

We prepared the MRGO via hummer's method followed by in-situ self-assembly co-precipitation of iron oxide nanoparticles. The results showed that the iron oxide nanoparticles was dispersed on the surface of graphene oxide. Furthermore, MRGO nanoparticles were developed as superparamagnetic nanoparticles. Adsorption experiment results showed that MRGO could absorbed nickel metal ion efficiently with the absorption ability around 78,24\% upon 30 minutes. Eventually, this result showed that MRGO have a potential prospect as an effective and efficient advanced adsorbent material candidate.

\section{ACKNOWLEDGEMENTS}

This work was supported by Indonesian Institute of Science.

\section{REFERENCES}

[1]. R. K. Upadhyay, N. Soin, and S. S. Roy. "Role of Graphene/Metal Oxide Composites as Photocatalysts, Adsorbents and Disinfectants in Water Treatment: a Review." RSC Advances, vol. 4, pp. 3823-3851. Jan. 2014.

[2]. A. H. Mevold, W. W. Hsu, A. Hardiansyah, L. Y. Huang, M. C. Yang, T. Y. Liu, et al.. "Fabrication of Gold Nanoparticles/Graphene-PDDA Nanohybrids for Bio-detection by SERS Nanotechnology." Nanoscale Res Lett, vol. 10, p. 397. Dec. 2015.

[3]. Z. Geng, Y. Lin, X. Yu, Q. Shen, L. Ma, Z. Li, et al.. "Highly Efficient Dye Adsorption and Removal: a Functional Hybrid of Reduced Graphene OxideFe3O4 Nanoparticles as an Easily Regenerative Adsorbent." Journal of Materials Chemistry, vol. 22, pp. 3527-3535. Feb. 2012.

[4]. X. Liang, B. Liang, Z. Pan, X. Lang, Y. Zhang, G. Wang, et al. "Tuning Plasmonic And Chemical Enhancement for SERS Detection on Graphenebased Au hybrids." Nanoscale, vol. 7, pp. 2018896. Dec. 2015.

[5]. Y. Gong, D. Li, Q. Fu, and C. Pan. "Influence of Graphene Microstructures on Electrochemical Performance for Supercapacitors." Progress in Natural Science: Materials International, vol. 25, pp. 379-385. Oct. 2015.

[6]. B. Chieng, N. Ibrahim, W. Wan Yunus, M. Hussein, and Y. Loo. "Effect of Graphene Nanoplatelets as Nanofiller in Plasticized Poly(Lactic Acid) Nanocomposites," Journal of Thermal Analysis and Calorimetry, vol. 118, pp. 1551-1559. Dec. 2014.

[7]. T. Zhou, X. Zhou, and D. Xing. "Controlled Release Of Doxorubicin from Graphene Oxide Based Charge-Reversal Nanocarrier." Biomaterials, vol. 35, pp. 4185-94. Apr. 2014. 
[8]. J.-H. Deng, X.-R. Zhang, G.-M. Zeng, J.-L. Gong, Q.-Y. Niu, and J. Liang. "Simultaneous Removal of Cd(II) and Ionic Dyes from Aqueous Solution Using Magnetic Graphene Oxide Nanocomposite as an Adsorbent." Chemical Engineering Journal. vol. 226, pp. 189-200, Jun. 2013.

[9]. W. Wu, Q. He, and C. Jiang. "Magnetic Iron Oxide Nanoparticles: Synthesis and Surface Functionalization Strategies." Nanoscale Research Letters, vol. 3, pp. 397 - 415. Oct. 2008.

[10]. A. Akbarzadeh, M. Samiei, and S. Davaran, "Magnetic nanoparticles: preparation, physical properties, and applications in biomedicine." Nanoscale Research Letters, vol. 7, p. 144. Feb. 2012.
[11]. L. Fan, C. Luo, X. Li, F. Lu, H. Qiu, and M. Sun. "Fabrication of Novel Magnetic Chitosan Grafted with Graphene Oxide to Enhance Adsorption Properties for Methyl Blue" Journal of Hazardous Materials, vol. 215-216, pp. 272-279. May. 2012.

[12]. J. Liu, Z. Sun, Y. Deng, Y. Zou, C. Li, X. Guo, et al. "Highly Water-Dispersible Biocompatible Magnetite Particles with Low Cytotoxicity Stabilized by Citrate Groups" Angewandte Chemie International Edition, vol. 48, pp. 5875-5879. Jul. 2009. 